\title{
PRODUCTION PROCESS INTENSIFICATION OF A SPECIFIC FRICTION BEARING BY CHANGE OF PRODUCTION TECHNOLOGY AND USED MATERIAL
}

\author{
${ }^{1}$ Dana STANČEKOVÁ, ${ }^{1}$ Milan SAPIETA, ${ }^{2}$ Anna RUDAWSKA, ${ }^{3}$ Nataša NÁPRSTKOVÁ, \\ ${ }^{1}$ Miroslav JANOTA
}

\author{
${ }^{1}$ University of Žilina, Žilina, Faculty of Mechanical Engineering, Slovak Republic, EU, \\ dana.stancekova@fstroj.uniza.sk, milan.sapieta@fstroj.uniza.sk \\ 2Lublin University of Technology, Faculty of Mechanical Engineering Poland, EU, a.rudawska@pollub.pl \\ 3J. E. Purkyne University in Usti nad Labem, Czech Republic, EU, Natasa.Naprstkova@ujep.cz \\ https://doi.org/10.37904/metal.2019.838
}

\begin{abstract}
The article analyses the state of the production process of the friction bearings into the NT compressor. The basis of this article is the production process of the friction bearing, where it was necessary to suggest a fundamental change for the intensification of the production. Significant change mainly concerns production technology, and consequently the design of material and semi-finished product from which the new friction bearing will be produced. An important part of the process is the design of the bearing, the technological process and the following testing and comparison by simulation of strength analyses of the model of the present and the designed bearing. The article compares production costs of the current and designed process also it evaluates investment and returns on the designed technology of production.
\end{abstract}

Keywords: Friction bearings, production technology, proposal, model, strength analysis

\section{INTRODUCTION}

The objective of our work was to design a modification of a construction and a production process of slide bearings that is formed and mounted as a component into a final product, namely a piston compressor in order to increase efficiency and economy of a production process. The design of the bearing production itself follows a construction design of the model of a given bearing and it provides performed analyses of strength of models of current bearings made of grey cast iron and also the designed bearing made of steel. Simulations were performed in the simulation environment of the software "Ansys" with the aim at compare and evaluate from the standpoint of strength load whether the current grey cast iron bearings can be substituted by the designed steel bearings.

\subsection{Sliding friction}

A main function of slide bearings as well as roller bearings is to guide or to support mutually moving parts. At same time, they must absorb arising forces and transmit them. While in case of roller bearings rolling elements are separated by rotating components, in slide bearings a rotating component moves along a sliding area of a stationary bearing bushing, bearing shell or a sliding belt, mostly along a shaft, a journal or a bar [1-4]. When constructing a bearing, one of key issues is a shape of sliding arrangement. Setting of the most sui-table shape of the sliding deposit is very significant for mutual positions of particular components that affect concentration of load in nodes together with a range of load of a bearing and a journal [5-8]. The operational reliability and durability of the arrangement of bearings depend on properties of the material couple a bearing and a shaft and on properties of lubrication in an individual design of the bearing. When selecting bearing materials, we follow construction parameters and operating conditions. Besides sliding properties it is necessary to consider a magnitude of forces, the nature of a load force, a range of sliding speeds and operating temperatures caused by them. For a proper selection of the bearing material we must consider its sliding, mechanical and physical properties, seizure resistance, fatique endurance, corrosion resistance and abrasion resistance $[9,10]$. 


\section{DESIGN OF NEW SLIDING BEARING}

Based on requirements that intend to develop production processes, we would simplify production, reduce production costs, increase productivity together with parameters related to productivity and, thus, we would obtain permanent excellence of given products.

\subsection{Overview of current state}

The designed sliding bearing "NT", as a component made of a casting from grey cast iron (Figure 1) is an important part of compressors in which it serves as an ancillary component to transfer forces between the frame and the shaft of the compressor (Figure 2). Their task consists in an absorbing of acting forces that arise when the compressor works.

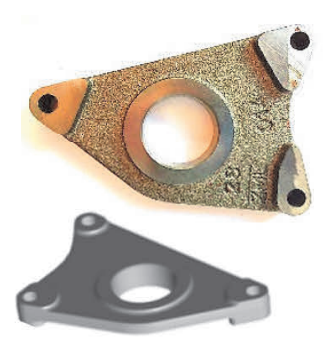

Figure 1 Bearing "NT"

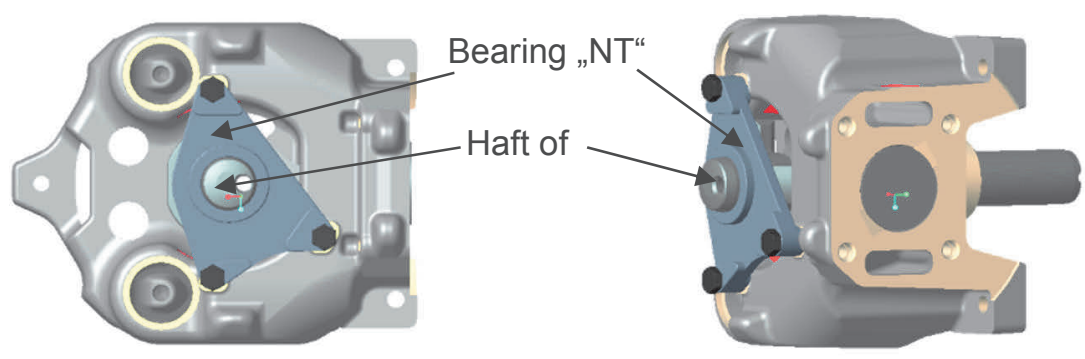

Figure 2 Mounting of Bearing "NT" on the shaft of the compressor

It was necessary to perform a comparison of material characteristics of selected bearings and also to simulate load on these bearing types so that we could substitute a current bearing type from grey cast iron by a bearing from steel. A simulation software Ansys was selected to perform strength analysis. The simulation provides a comparison and evaluation of a load impact on the present-day bearing from standard grey cast iron and on the designed bearing from steel.

\subsection{Comparison of material characteristicsk}

Current material, grey cast iron: it is defined by the company standard as a material applied in production of smaller parts, e.g., a valve plate, bearings, cylinder heads, etc.). Typical feature of the material is its good machinability and mechanical and absorptive properties, Table 1.

Designed material, steel: it is defined by the EN 10111/08 standard as KOHAL DD14. It is a ductile steel sheet from low carbon steel suitable for deep-drawing and cold forming, Table 1.

Table 1 Basic chemical composition and mechanical properties of applied grey cast iron and steel

\begin{tabular}{|c|c|c|c|c|c|c|c|c|c|c|}
\hline & \multicolumn{9}{|c|}{ Chemical element - content (wt.\%) } & \multicolumn{3}{c|}{ mechanical properties } \\
\cline { 2 - 11 } & $\mathrm{C}$ & $\mathrm{Mn}$ & $\mathrm{P}_{\max }$ & $\mathrm{S}_{\max }$ & $\mathrm{Si}_{\max }$ & $\mathrm{Cr}_{\max }$ & $\mathrm{Ni}_{\max }$ & $\mathrm{Al}$ & $\begin{array}{c}\text { Yield strength } \\
R_{e}[\mathrm{MPa}]\end{array}$ & $\begin{array}{c}\text { Tensile strength } \\
R_{m}[\mathrm{MPa}]\end{array}$ \\
\hline grey cast iron & $3.00-3.70$ & $0.50-1.00$ & 0.35 & 0.150 & $1.7-2.65$ & 0.45 & 0.20 & - & 130 & 220 \\
\hline steel & 0.06 & 0.30 & 0.02 & 0.015 & 0.030 & - & - & 0.020 & 270 & 360 \\
\hline
\end{tabular}

\section{SIMULATION OF BEARING LOADS}

\subsection{Simulation to define magnitude of force inside bearing}

It is necessary to perform an auxiliary simulation to find out a magnitude of load in the bearing arrangement. Besides knowledge of material characteristics, further input information is important to perform simulation, and, 
thus, the maximum tip pressure. It is $18 \mathrm{MPa}$. The pressure is applied on the piston surface area SA at the moment when the piston is located in the top dead centre (Figure 3). The surface area is $865 \mathrm{~mm}^{2}$. In the simulation environment was calculated force $F=15,570 \mathrm{~N}$ as a load quantity from pressure load.

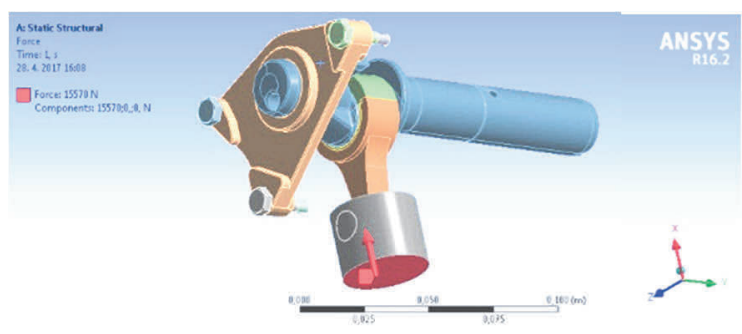

Figure 3 Force applied in top dead centre

The aim of the simplified simulation is to define applied forces, resp. a load in the position of the bearing arrangement. The analysis results in the fact that a magnitude of applied forces in the position of the bearing arrangement is $F=6,430 \mathrm{~N}$ (Figures 4 and 5). This value will be used as a basis for further strength analyses.

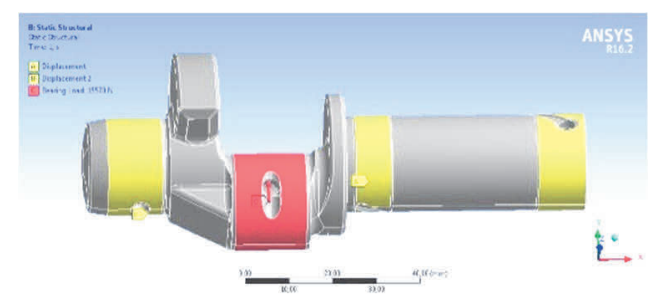

Figure 4 Boundary conditions

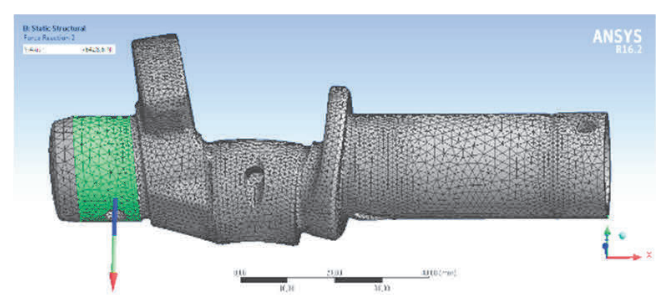

Figure 5 Value of force applied in place of bearing mounting

\subsection{Strength analysis of bering "NT"}

In this analysis we load the bearing with the required force $\mathrm{F}$. A simulation is performed for a current bearing model "NT" from grey cast iron) and also for a designed bearing model "NT" from steel sheet. Firstly, we formed a suitable and quality network for both models (Figure 6) to perform the analysis most accurately. Sizes of net elements were selected at $0.75 \mathrm{~mm}$.

a)

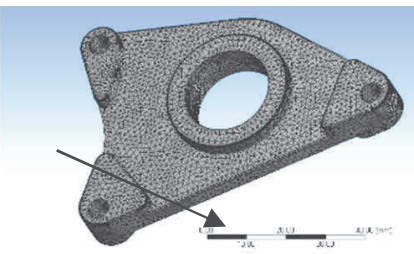

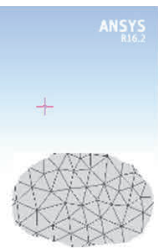

b)

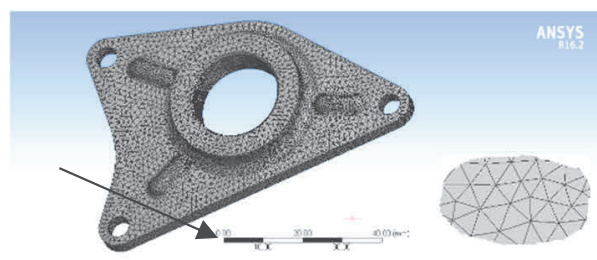

Figure 6 Net with details- a) grey cast iron model, b) steel model

Input information is material characteristics, the stated load force $\mathrm{F}$ (Figures $7 \mathbf{a}, \mathbf{b}$ ) and other boundary conditions that are stated in photographs from the simulation environment software (Figures 7c, d). Output of simulations is a comparison of the given model types and evaluation whether the bearing model from steel sheet is a suitable alternative for a bearing from grey cast iron from the standpoint of load and strength.

a)

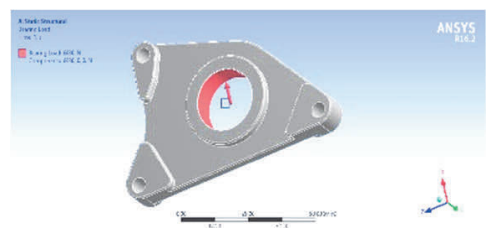

b)

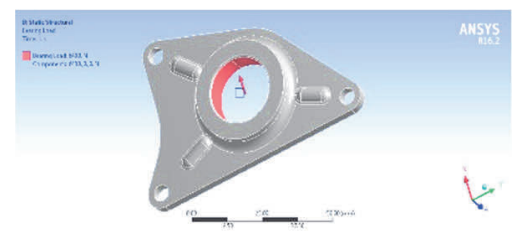


C)

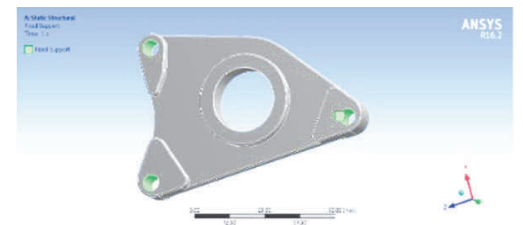

Figure 7 Boundary condition, mounting of fixed points a) grey cast iron, b) steel

After formation of a suitable finite element network on bearing models as well as definition of boundary conditions a possibility of total deformation, i.e., total yield and equivalent stress, i.e., reduced stresses were selected as suitable for a comparison of bearing models.

a)

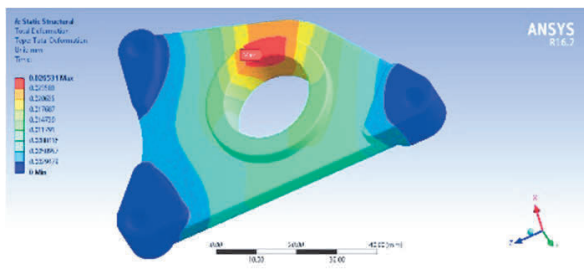

c)

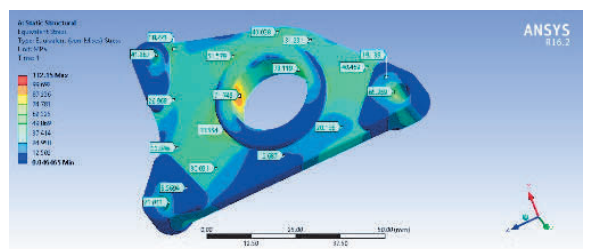

e)
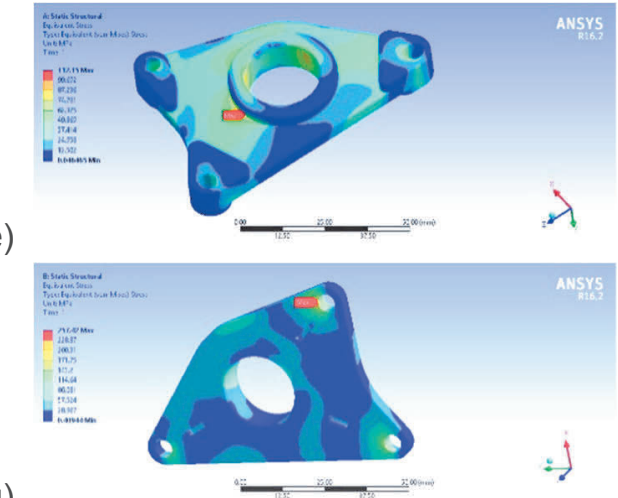

g)

Figure 8 a) grey cast iron model, b) steel model (total deformation); c) grey cast iron model, d) steel model

(stresses: total overview); e) position of maximum stress in grey cast iron model, f) position of stress, compared with maximum value of stress in grey cast iron model and in steel model in the same point; g) position of maximum stress in steel model h) position of stress, compared with maximum value of stress in grey cast iron model and in steel model in the same point

\subsection{Solution}

Total deformation, total yield is based on a conducted analysis of total yield and obtained results we may assume that rigidity of the designed steel bearing is comparable with rigidity of the original grey cast iron bearing. The value of rigidity of the designed bearing is $0.0394 \mathrm{~mm}$ against the value of the original bearing $0.0265 \mathrm{~mm}$ which means the negligible difference of $0.0129 \mathrm{~mm}$ - see Figures $8 \mathbf{a}, \mathbf{b}$. Equivalent stress, reduced stresses, the overall view - distribution of stress fields in a new and original bearing variant is of a similar shape without sudden stress changes - see Figures 8c, d. Equivalent stress, a comparison of the position of maximum stress on the bearing model from grey cast iron against the same position on the bearing model from steel - the value of the maximum reduced stress in the original grey cast iron bearing represents 
stress $112.15 \mathrm{MPa}$ as shown in Figure 8e. Value of the designed steel bearing is in the same point 115.31MPa, Figure 8f. The result is that values of reduced stress have similar values in the same points. Equivalent stress", a comparison of maximum stress in the bearing model from steel against the same position in the bearing model from grey cast iron - in this comparison the maximum value sharply differs, i.e., $257.42 \mathrm{MPa}$ (Figure $\mathbf{8 g}$ ) of reduced stress of the designed steel bearing against the value $68.563 \mathrm{MPa}$ (Figure $8 \mathrm{~h}$ ) of the original grey cast iron bearing. The reason is that the model of the original bearing is more robust in the point of the maximum value of stress of the designed model, i.e., larger width in the point of mounting of screws. Another factor of the sharp difference between stresses is an impact of an existence of a boundary condition of the type "fix" on walls of the hole which may misrepresent the maximum stress value.

The evaluation of the analysis of strength of "NT" bearing. The following facts were found out after conducting of strength calculations:

- from the standpoint of total yield, i.e., rigidity, the model of the designed steel bearing is comparable with the original grey cast iron bearing,

- $\quad$ from the standpoint of strength, results show a similarity of distribution of stress fields in the new and original variants, although maximum values differ more sharply. However, the difference is caused by the above-stated construction of bearing elements and the boundary condition.

Fundamental information for the evaluation of simulations is a fact that the analysis was conducted by the maximum pressure of the compressor $18 \mathrm{MPa}$ and also consequent analyses resulted from the value. However, the maximum working compression of the compressor is $2.8 \mathrm{MPa}$, which is a substantially lower value as we applied in strength analyses. As a comparison, a value of applied pressure $2.8 \mathrm{MPa}$ on a force $F$ $=2,422 \mathrm{~N}$ was calculated and also an ancillary analysis was conducted to define an applied force in the point of the bearing arrangement. The force is $F=1,000 \mathrm{~N}$ after rounding off. The force is applied to load the model of the designed bearing so that the result of strength analysis can be compared by the pressure of $18 \mathrm{MPa}$ (Figures 8e, f) and 2.8 MPa (Figure 9).

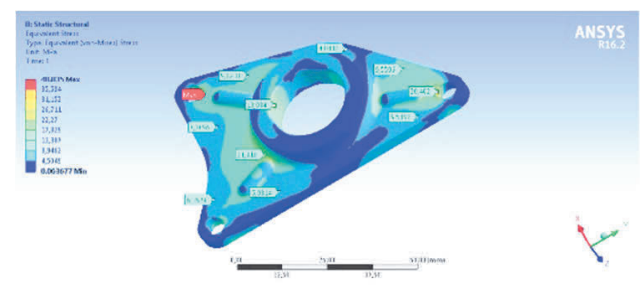

Figure 9 Analysis of strength by pressure $2.8 \mathrm{MPa}$, steel model

The output of comparisons of stress and strength is a statement that the designed steel bearing model complies with conditions and it is a suitable substitution for the original grey cast iron model. Based on mechanical properties of steel, the value of maximum stress is $257.42 \mathrm{MPa}$ in case of the steel model is close to the maximum yield strength $R_{e}=270 \mathrm{MPa}$. However, that value steel meets the standard and it does not exceed the permitted value. As mentioned above, the maximum stress is affected by the boundary condition "fix" on walls of the hole. Moreover, another important factor was that simulations were conducted by the maximum test load of $18 \mathrm{MPa}$. The designed bearing is suitable for 100 per cent for the application by a maximum working pressure of $2.8 \mathrm{MPa}$ by which is the value of stress $40.035 \mathrm{MPa}$.

\section{CONCLUSION}

The implied experimental verifications were processed according to requirements of a company that tries to improve production processes. Based on the conduction of the analysis of total stresses and obtained results, we may assume that rigidity of the designed steel bearing is comparable with rigidity of the original grey cast 
iron bearing. A value o frigidity of the designed bearing is $0.0394 \mathrm{~mm}$ against rigidity of the original bearing $0.0265 \mathrm{~mm}$. That means the difference of $0.0129 \mathrm{~mm}$. We may assume that the difference is negligible in this mechanical system. From the standpoint of strength, results confirm a similarity in a distribution of stress fields in the new and old variants even though the maximum stresses differ more sharply. The difference is caused by a construction of bearing elements and a boundary condition. The outcome of comparisons of stress and strength is a statement that the designed steel bearing model complies with conditions and it can replace the original grey cast iron model.

\section{ACKNOWLEDGEMENTS}

The article was made under support grant project KEGA 022ŽU-4/2017 Implementation of on-line education in the area of precise technologies with an impact on educational process to increase skills and flexibility of students of engineering fields of study.

\section{REFERENCES}

[1] BARYSZ, I. KIzné uloženie - konštrukčné a teoretické riešeni. 1st ed. Žilina: VŠDS v Žiline, 1995, p. 523.

[2] http://www.schaeffler.sk/content.schaeffler.sk/sk/products services/rotativ products/index.js [13. 11. 2016]

[3] SCHINDLEROVÁ, V., ŠAJDLEROVÁ, I. and MOHYLA, P. (2016). Optimization of metallurgical processes using dynamic simulation. In METAL 2016: 25th International Conference on Metalurgy and Materials. Ostrava: TANGER, 2016, pp. 2013-2018.

[4] RADVANSKÁ, A., HREHA, P., KNAPČíKOVÁ, L., PETRŮ, J., ZLÁMAL, T. and MONKA, P. Influence of focusing tube wear on vibrations and surfaces roughness Tehnicki Vjesnik.2015. vol. 22, no. 2, pp. 271-278.

[5] STANČEKOVÁ, D., ŠEMCER, J., DERBAS, M. and KURŇAVA, T. Methods of measuring of residual stresses and evaluation of residual state of functional surfaces by x-ray diffractometric methods. Manufacturing Technology. 2013. vol. 13, no. 4, pp. 547-552.

[6] KALINCOVA, D., TAVODOVA, M., HNILICOVA, M. and VEVERKOVA, D. Machinery for forest cultivation Increase of resistance to abrasive wear of the tool. MM Science Journal. 2016. pp. 1269-1272.

[7] NOVOTNÝ, J., LYSONKOVA, I., NAPRSTKOVA, N. and MICHNA, S. Research of application possibilities of selected mechanically alloyed metal powders. Manufacturing Technology. 2017. vol. 17, no. 5, pp. 811-815.

[8] ZAUSKOVA, L., CZAN, A., SAJGALIK, M., DRBUL, M. and RYSAVA, Z. Triaxial Measurement of Residual Stress after High Feed Milling Using X-ray Diffraction. Procedia Engineering. 2017. vol. 192, pp. 982-987.

[9] http://help.autodesk.com/view/INVNTOR/2016/CSY/?guid=GUID-81D3E98C-7F3D-4DF8-8550-DE3401E7147C, [19. 11. 2016]

[10] DUPLÁK, J., ZAJAC, J., HATALA, M., MITAL', D. and KORMOŠ, M. Study of surface quality after turning of steel AISI 304. Manufacturing Technology. 2014. vol. 14, no. 4, pp. 527 - 532 